\title{
Role of Polypeptide GalNAc-transferase T3 in Familial Tumoral Calcinosis: The Importance of a Single GalNAc-transferase Isoform
}

\author{
家族性腫瘍状石灰化症におけるポリペプチド GalNAc 転移酵素 T3 の役割：GalNAc 転移酵素の \\ 1 アイソフォームの重要性
}

\begin{abstract}
Kato, Kentaro; and Clausen, Henrik
Department of Cellular and Molecular Medicine, University of Copenhagen, Blegdamsvej 3, DK-2200 Copenhagen N, Denmark FAX: 45-3536-7980, E-mail: kentaro@imbg.ku.dk, hc@imbg.ku.dk
\end{abstract}

Key Words: O-glycosylation, GalNAc-transferase, GalNAc-T3, FGF23, protein secretion

\begin{abstract}
UDP-GalNAc: polypeptide N-acetylgalactosaminyl transferase (GalNAc-transferase, GalNAc-T) is the enzyme catalyzing mucin-type $O$-glycosylation (GalNAc $\alpha 1-O$ Ser/Thr) of proteins. Mutations in the gene encoding the GalNAc-T3 isoform were recently identified as a cause of the autosomal recessive metabolic disorder familial tumoral calcinosis (FTC) (OMIM 211900). FTC is associated with hyperphosphatemia and massive ectopic calcifications. We recently demonstrated that the secretion of the phosphaturic factor FGF23 requires $O$-glycosylation, and that GalNAc-T3 selectively directs $O$-glycosylation in a subtilisin-like proprotein convertase recognition sequence motif, which blocks furin protease processing of FGF23 (1). These results suggest a novel posttranslational regulatory model of FGF23 involving competing $O$-glycosylation and protease processing to produce intact FGF23.
\end{abstract}

\section{A. GalNAc-Transferase}

The UDP-GalNAc: polypeptide N-acetylgalactosamin yltransferase (GalNAc-transferase) gene family is the largest mammalian family of glycosyltransferases, which is involved in catalysis of a single glycosidic linkage, GalNAca1-OSer/Thr, in the Golgi complex (2). The GalNAc-tranferase gene family contains 20 genes of which fifteen have been shown to encode functional enzymes so far. $O$-glycosylation imparts unique physicochemical features to glycoproteins and $O$-glycans and has been shown to play important functions in biological processes including intracellular sorting, cellcell adhesion, and microbial adhesion events. The large number of GalNAc-transferase isoforms available has been interpreted to provide a high degree of redundancy, and in fact ablation studies in mice have not yet provided unambiguous information of unique roles for individual GalNAc-transferase isoforms (3-5), although a recent reinvestigation of GalNAc-T1
要 約

UDP-GalNAc：ポリペプチドN-アセチルガラクトサミン 転移酵素 (GalNAc- 転移酵素、GalNAc-T) はタンパク質のムチ ン型 O- グリコシレーション (GalNAcal-O-Ser/Thr) を触媒す る酵素群である。GalNAc-T3 の遺伝子変異が常染色体劣性代 謝性疾患である家族性腫瘍状石灰化症 (familial tumoral calcinosis、FTC)(OMIM 211900) の原因となることが近年明らかに された。FTC は高リン血症抢よび異所性石灰化を伴う。我々 はリン酸代謝調節因子である FGF23 の分泌にO-グリコシレー ションが必要であること、および GalNAc-T3 がスブチリシン 様プロプロテインコンベルターゼにより認識される配列を特 異的にO-グリコシレーションし、その修飾が furin プロテアー ゼによる FGF23 のプロセシングを阻害することを明らかにし た (1)。これらの結果は完全長の FGF23 を産生する際の $O$-グ リコシレーションとプロテアーゼによるプロセシングとの競 合、という FGF23 の新規翻訳後修飾制御モデルを示唆してい る。

\section{A.GalNAc 転移酵素}

UDP-GalNAc：ポリペプチドN-アセチルガラクトサミン 転移酵素 (GalNAc 転移酵素) 遺伝子ファミリーは哺乳類の糖 転移酵素ファミリーの中では最大のファミリーであり、ゴル ジ体に扔いてグリコシド結合、GalNAcal-O-Ser/Thr、を触媒 している (2)。GalNAc 転移酵素遺伝子ファミリーには 20 種類 の遺伝子が含まれ、現在までにそのうちの 15 種類が機能的な 酵素をコードしていることが示されている。O-グリコシレー ションは糖タンパク質および $O$ - 結合型糖鎖に独特な物理化学 的特性を与え、細胞内選別輸送、細胞間接着、および微生物 付着などの生物学的プロセスに扔いて重要な役割を果たして いることが示されている。GalNAc 転移酵素に多くのアイソ フォームが存在することは咒長性を示すものであると解釈さ れて抢り、実際にノックアウトマウスを用いた研究に执いて も GalNAc 転移酵素の個々のアイソフォームに独特な役割が 存在することは現在までのところ明らかにされていない(3-5)。 
ablated mice appears to have defects in lymph node B-cell retention (6). A case for unique in vivo functions of GalNActransferase isoforms was, however, provided by studies in D.melanogaster, where it was found that a single GalNActransferase isoform out of 15 putative GalNAc-transferase genes in Drosophila was essential for pupal development $(7,8)$. Although the molecular basis for this is unknown, the result clearly points to unique non-redundant functions of GalNActransferase isoforms. Recently, one of the GalNAc-transferase isoforms, GalNAc-T3 was implicated in familial tumoral calcinosis (FTC) (9-17).

\section{B. Secretion of FGF23 Is Dependent on GalNAc O-Glycosylation}

In the recent study, we have addressed the functional role of $O$-glycosylation of the phosphaturic factor, fibroblast growth factor 23 (FGF23), by the GalNAc-T3 isoform (1). FGF23 is a key regulator of phosphate homeostasis $(18,19)$. FGF23 is partially processed in the trans-Golgi network by subtilisin-like proprotein convertases (SPC) at the consensus sequence RxxR_ $\left(\right.$ RHTR $^{179}$ ) between $\operatorname{Arg}^{179}$ and $\operatorname{Ser}^{180}$ (20 -22). This processing step appears to be essential in the regulation of phosphate homeostasis, since mutations in the SPC cleavage sequence prevent processing and result in autosomal dominant hypophosphatemic rickets (ADHR) (18). Conversely, ablation of FGF23 in mice leads to hyperphosphatemia resembling FTC (23), and more recently, FGF23 mutations affecting folding and secretion rather than processing have been identified in FTC patients without mutations in GalNAc-T3 (24-26). FGF23 is an $O$-glycosylated glycoprotein of approximately $32 \mathrm{kDa}$, and $O$-glycosylation has been identified in proximity to the SPC cleavage signal although the actual site of attachments has not been defined yet $(15,20)$. GalNAc-T3 and FGF23 were found to be coexpressed in a number of tissues (10). FTC patients with GalNAc-T3 mutations have been reported to have an apparent elevation of FGF23 serum levels (20-40 fold) $(9,27)$, which is in conflict with the finding that FTC patients can have mutations in FGF23 that blocks secretion (26). However, the immunoassay used to detect FGF23 in these patients detects the processed C-terminal fragment and evidence of increased levels of intact active FGF23 are missing $(9,28)$.

We considered FGF23 as a prime candidate for specific $O$-glycosylation by GalNAc-T3 based on sequence analysis. We tested this hypothesis using the CHO ldlD system. CHO ldID cells are deficient in the UDP-Gal/UDP-GalNAc 4-epimerase which catalyzes the reaction from UDP-glucose to UDP-galactose and UDP-GlcNAc to UDP-GalNAc. Therefore, CHO ldlD cells cannot synthesize $O$-glycan on proteins by themselves. The defect can be selectively restored by addition of GalNAc and/or Gal. Interestingly, addition of
しかしながら GalNAc-T1ノックアウトマウスを再試験した結 果、リンパ節に扔ける B 細胞保持に異常が認められている (6)。 In vivo に打ける GalNAc 転移酵素アイソフォームの特性を示 す一例はD.melanogasterに扔いて示されており、推定される 15 種類の GalNAc 転移酵素遺伝子のうちの 1 つが Drosophila の蛹形成に必須であることが示されている $(7 、 8)$ 。この分子 機構は明らかでないが、この結果は GalNAc 転移酵素アイソ フォームに独特の、朵長ではない機能が存在することを示し ている。近年、GalNAc 転移酵素の1つのアイソフォームであ る、GalNAc-T3 の家族性腫瘍状石灰化症 (FTC)への関与が示 されている (9-17)。

B.FGF23 の分泌には GalNAc O- グリコシレーションが必要 である

最近、我々はリン酸代謝調節因子である繊維芽細胞増殖 因子 23(FGF23) の GalNAc-T3 によるO-グリコシレーション の機能的役割について検討した (1)。FGF23 は生体リン恒常性 維持に扔ける重要な因子である(18、19)。FGF23 はトランスゴ ルジネットワークに打いて部分的にスブチリシン様プロプロ テインコンベルターゼ (SPC)により、切断のコンセンサス配 列である RxxR_ $\left(\mathrm{RHTR}^{179}\right)$ が存在する $\mathrm{Arg}^{179}$ および $\mathrm{Ser}^{180}$ の 間で切断される (20-22)。SPCによる切断部位に変異が存在す るとプロセシングが阻害され常染色体優性低リン血症性くる 病 (ADHR) の原因となることから (18)、このプロセシングが 生体リン恒常性維持には重要であると考えられる。逆にマウ スに損いてFGF23 を欠損させると FTCのような高リン血症 状態を引き起こし(23)、さらにGalNAc-T3 に変異が見られな いFTC 患者に执いてFGF23 の遺伝子変異が FGF23 のプロ セシングではなくフォルディングや分泌に影響を与えること が報告されている (24-26)。FGF23 は $O$ - 結合型糖鎖を有する $32 \mathrm{kDa}$ の糖タンパク質であり、SPCによる切断部位近傍に $O$ 結合型糖鎖の存在が示唆されているが、正確な位置について は明らかになっていない $(15 、 20) 。$ GalNAc-T3 と FGF23 はい くつかの組織において共発現することが報告されている $(10) 。$ GalNAc-T3 に変異を有するFTC 患者ではFGF23 の血清レ ベルの上昇が認められ (20-40 倍)(9、27)、FTC 患者の中には FGF23 の分泌を抑制する遺伝子変異を有する患者がいること と矛盾する (26)。しかしながら、FGF23 の検出に用いられた イムノアッセイはプロセシングを受けた C 末端断片も検出す ることから、完全長の FGF23 の血清レベルも上昇するかは不 明である (9、28)。

我々はFGF23 のアミノ酸配列より FGF23 が GalNAc-T3 により特異的にO-グリコシレーションされるであろうと考え た。この仮説を検証するためにCHO ld lD 細胞システムを用 いた。CHO ldlD 細胞は UDP-glucose を UDP-galactose、ある いは UDP-GlcNAc を UDP-GalNAc に転換する UDP-Gal/UDPGalNAc 4-エピメラーゼを欠損している。したがって、CHO $1 \mathrm{dlD}$ 細胞自身は夕ンパク質上に $O$ - 結合型糖鎖を合成すること ができない。この久損は GalNAc および/あるいは Gal を培地 に添加することで選択的に回復させることができる。興味深 


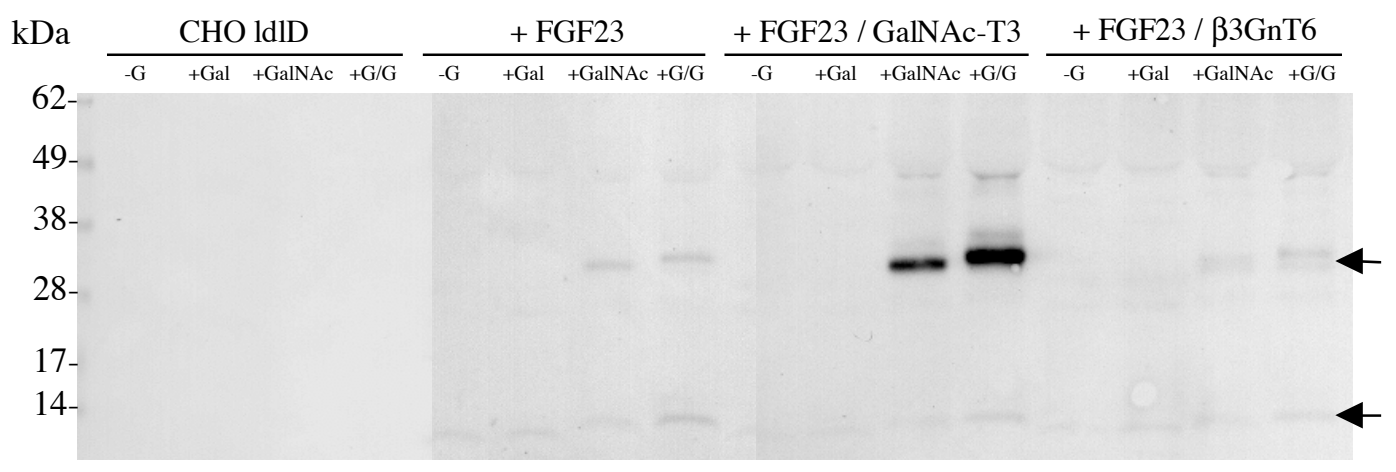

Fig.1. Anti-myc SDS-PAGE Western blot analysis of culture medium of CHO IdID cells (adapted from ref.1).Culture media after $72 \mathrm{hr}$ growth were collected and applied to SDS-PAGE. Intact and cleaved FGF23 were detected by anti-myc antibody. Designations: -G, no sugars added; +G/G, both Gal and GalNAc added.

GalNAc alone results in $O$-glycosylation limited to GalNAc with no apparent elongation or sialylation (29), whereas the substitution of GalNAc and Gal leads to a complete restoration of $O$-glycosylation.

As shown in Fig.1, secretion of FGF23 in CHO ldlD cells requires at least $O$-glycosylation with GalNAc, and the level of secretion is dramatically increased when GalNAc-T3 is co-expressed. All cells were characterized for expression of respective genes by immunocytology and SDS-PAGE Western blot analysis. The control $\beta 3 \mathrm{GnT} 6$ is the enzyme that resides in Golgi apparatus and has a role in elongation of Tn to core 3 structures (GlcNAc $\beta 1-3$ GalNAca1-O-Ser/Thr). CHO ldlD cells grown in both GalNAc and Gal produce sialylated core 1 structures, which should account for the apparent higher molecular weight. A faint band of approximately $14 \mathrm{kDa}$ was also observed in medium from all cells, which represents the C-terminal myc-tagged fragment (20). Levels of secreted FGF23 from CHO 1dlD FGF23 and the double FGF23 and $\beta 3 \mathrm{GnT} 6$ transfectants showed low levels, while the GalNAc-T3 transfectant cells showed a marked increase. This increase was especially significant with cells grown in both GalNAc and Gal, which suggests that GalNAc-glycosylation alone promotes secretion to a lesser degree than the more complex glycosylation achieved with addition of Gal and GalNAc.

\section{Unique GalNAc-T3 Mediated $O$-Glycosylation of Peptide Substrates from FGF23}

To further explore the role of GalNAc-T3, we tested a panel of recombinant human GalNAc-transferases with peptide substrates designed to cover potential $O$-glycosylation sites in FGF23. Shimada et al. (20) found evidence of variable $O$-glycosylation in two peptide fragments (a.a.162-175 (1 site), a.a.176-187 (2 sites)) around the furin protease processing site and also $O$-glycosylation in a more C-terminal fragment
いことに GalNAc のみを添加した場合は $O$ - グリコシレーショ ンは糖鎖の伸長およびシアリル化を受けることなくGalNAc で止まる (29) が、GalNAc および Gal を添加することで完全な $O$ - 結合型糖鎖を合成できるようになる。

図1に示したようにCHO ldlD 細胞からの完全長の FGF23 分泌には少なくともGalNAcによるO-グリコシレー ションが必要であり、GalNAc-T3を共発現させた場合には その分泌レベルが劇的に上昇した。すべての細胞における 遺伝子産物の発現は免疫細胞学的手法ならびにSDS-PAGE ウェスタンブロット法により確認した。対照として導入し た $\beta 3 \mathrm{GnT}$ T6 はゴルジ体に存在する酵素で Tn 抗原をコア 3 構 造 (GlcNAcß1-3GalNAca1-O-Ser/Thr) に伸長する酵素である。 GalNAc および Gal 存在下で培養された $\mathrm{CHO}$ ldlD 細胞はシア リル化されたコア 1 構造を産生するため、より分子量の大き い分子を分泌する。すべての細胞において観察される分子量 約 $14 \mathrm{kDa}$ のバンドは myc 標識された C 末端断片である (20)。 CHO ldID FGF23 細胞およびFGF23 と $\beta 3 \mathrm{GnT} 6$ を共発現させ た細胞における FGF23 の分泌レベルは低いがGalNAc-T3を 共発現させた細胞では有意に分泌レベルが上昇した。この上 昇はGalNAc およびGal を添加した培地で培養した場合に顕 著であり、GalNAcのみの O-グリコシレーションでは Gal お よびGalNAcを添加した場合の高度なグリコシレーションが 起きている場合に比べ分泌の促進度合いは低かった。

\section{C.FGF23 由来ペプチド基質に対する GalNAc-T3 の特異性 \\ GalNAc-T3 の役割をさらに検証するために我々は数種類 の組換え型ヒト GalNAc 転移酵素と FGF23の O-グリコシレー ション部位を網羅するように設計したペプチド基質を反応さ せた。Shimadaら (20) は PEAKrapid 細胞に発現させた変異 型 FGF23(R176Q およびR179Q) において、furin プロテアーゼ 近傍の 2 つのペプチド断片 (アミノ酸 162-175(1 ヶ所)、アミノ 酸 176-187(2 ケ所))に $O$ - グリコシレーションが存在すること を示しており、さらにC 末端側(アミノ酸 199-228)にも $O$-グ}




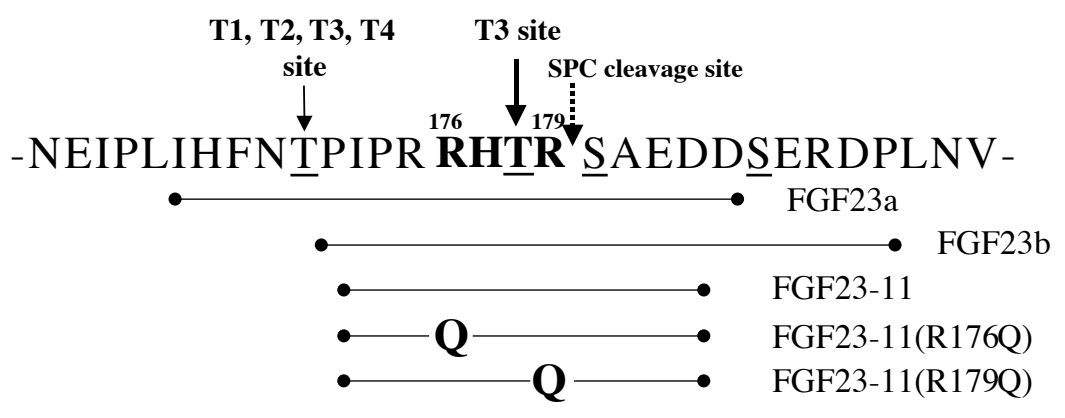

Fig.2. Schematic representation of FGF23 peptides used in vitro assay and summary of substrate specificities of GalNAc-T1, T2, T3, and T4 toward those peptides. GalNAc-attached sites were confirmed by MALDI-TOF mass spectrometry and furin cleavage assay.

(a.a.199-228) of mutant FGF23 (double R176Q and R179Q) expressed in PEAKrapid cells. The actual sites of attachments have not been defined. We focused on the potential Ser/Thr sites around the RHTR furin protease cleavage signal (Fig. 2). GalNAc-T3 was tested together with three other broadly expressed isoforms, GalNAc-T1, -T2 and -T4, with different acceptor substrate specificities $(30,31)$. While all isoforms utilized Thr ${ }^{171}$, only GalNAc-T3 incorporated GalNAc into $\mathrm{Thr}^{178}$. The site of incorporation was determined by MALDITOF analysis of the furin protease cleaved product of FGF23b glycopeptides, where the N-terminal peptide fragment was found as the expected mass plus the saccharide component. The studies of $O$-glycosylation of mutant FGF23 by Shimada et al. (20) are in agreement with the in vitro $O$-glycosylation of $\mathrm{Thr}^{178}$ as they found two $O$-glycans in the peptide fragment ${ }^{176}$ QHTQSAEDDSER ${ }^{187}$ with three potential acceptor sites of which $\mathrm{Thr}^{178}$ and $\operatorname{Ser}^{180}$ are most likely sites.

\section{Specific $\boldsymbol{O}$-Glycosylation of FGF23 Blocks Furin Protease Cleavage of FGF23 Peptides}

The peptide FGF23b, which contain the GalNAc-T3 $\mathrm{Thr}^{178}$ glycosylation site, was used for further studies of the effect of $O$-glycosylation for in vitro furin protease cleavage. To demonstrate the validity of this assay, we tested two mutant peptides based on identified mutations in the furin cleavage signal in patients with autosomal dominant hypophosphatemic rickets $(18,22)$. The wildtype sequences $\left({ }^{176}\right.$ RHTR $\left.^{179}\right)$ were efficiently cleaved to the expected fragments, while the R179Q mutant peptide was completely resistant and the R176Q peptide partially resistant to cleavage. A series of glycopeptides with all the expected $O$-glycan glycoforms, which can be produced in $\mathrm{CHO}$ cells, were enzymatically synthesized and tested in the furin cleavage assay. Interestingly, GalNAc alone or Gal $\beta 1$-3GalNAc did not seem to have significant inhibitory effect, while $\alpha 2$,6sialylation on either core blocked cleavage. The $\alpha 2,3$ sialylation of Gal $\beta 1-3$ GalNAc did not significantly block either suggesting that the major inhibitory
リコシレーションが存在することを示している。 $O$ - 結合型糖 鎖が存在する正確な位置は明らかではない。我々は furin プロ テアーゼ認識部位である RHTR 配列近傍の Ser/Thr 残基に着 目した (図 2)。GalNAc-T3 と共に、異なる基質特異性を有し 広範に発現が認められている他の 3 つのアイソフォーム、Gal-

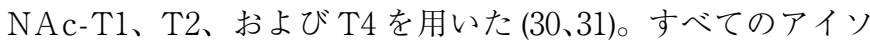
フォームが Thr ${ }^{171}$ に GalNAc を転移したが、GalNAc-T3のみ が Thr ${ }^{178} に も$ GalNAc を転移した。GalNAc 付加位置はfurin プロテアーゼにより切断した産物を MALDI-TOF MS で解析 し、N 末端側のペプチド断片が、予想される分子量に GalNAc が付加した分子量であったことから同定した。Shimada ら (20) の変異型 FGF23 の $O$ - グリコシレーション部位に関する検討 では ${ }^{176} \mathrm{QHTQSAEDDSER}{ }^{187}$ において、可能性のある 3 ヶ所の うちの 2 ヶ所 $\left(\mathrm{Thr}^{178}\right.$ および $\mathrm{Ser}^{180}$ の可能性が高い)に $O$ - 結合 型糖鎖が付加していることが示されており、我々の in vitroに おける検討で $\mathrm{Thr}^{178}$ が $O$-グリコシレーションされるという結 果と矛盾しない。

D.FGF23 上の特異的な O- 結合型糖鎖が furin プロテアーゼに よるFGF23 ペプチドの切断を阻害する

GalNAc-T3 によるグリコシレーション部位である Thr ${ }^{178}$ を有する FGF23b ペプチドを用いて in vitroにおける furin プ ロテアーゼによる切断に対する $O$-グリコシレーションの効果 を調べた。このアッセイの妥当性を調べるために常染色体優 性低リン血症性くる病 (ADHR) 患者の furin による FGF23 切 断配列に同定された変異 $(18 、 22)$ に基づき設計した 2 種類のぺ プチドを用いた。野生型配列 $\left({ }^{176} \mathrm{RHTR}{ }^{179}\right)$ は予想された断片 に完全に切断されたが、R $179 \mathrm{Q}$ 変異ペプチドは切断されず、 $\mathrm{R} 176 \mathrm{Q}$ 変異ペプチドは抵抗性を有していた。CHO 細胞におい て産生されうる $O$ - 結合型糖鎖を有するぺプチドをすべて酵素 学的に用意し、furin 切断アッセイを行った。興味深いことに

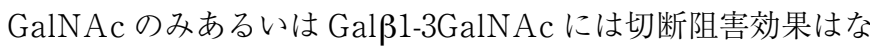
かったが、両コア構造を $\alpha 2,6$ シアリル化した場合に切断阻害 が認められた。Gal $\beta 1-3 G a l N A c を \alpha 2,3$ シアリル化した場合に は有意な切断阻害効果がみられなかったことから内部 STn コ 
effect is exerted by the inner STn core structure (NeuAc $\alpha 2-$ 6GalNAca1-O-Thr).

The initiation step of mucin-type $O$-glycosylation is clearly the single glycosidic linkage covered by the highest degree of potential biosynthetic redundancy. Yet, as found in this study, GalNAc-transferase isoforms may serve unique functions in cells where the repertoire of isoforms does not represent appropriate redundancy. The GalNAc-T3 and -T6 subfamily isoforms have identical substrate specificities as revealed by in vitro analysis, however, the two isoforms have markedly different cell and tissue expression patterns (32). The finding that GalNAc-T3 deficiency results in such a limited and defined molecular defect is intriguing and may predict the existence of other distinct diseases associated with deficiencies in polypeptide GalNAc-transferase genes. In summary, the study presents the first molecular basis of a disease, hyperphosphatemia in FTC, associated with mutations in a specific GalNAc-transferase isoform.
ア構造 (NeuAca2-6GalNAca1-O-Thr)により主に阻害効果が得 られると考えられる。

ムチン型 $O$-グリコシレーションの開始段階は明らかに最 も高い圥長性を有する1つのグリコシド結合である。しかし、 本研究で明らかになったように、アイソフォームのレパート リーが完全な冗長性を示さない細胞内においては GalNAc 転 移酵素のアイソフォームが独特な機能を有している可能性が ある。GalNAc-T3 およびT6アイソフォームは in vitro では同 一の基質特異性を有しているが、全く異なる細胞拧よび組織 発現パターンを有している (32)。GalNAc-T3 の欠損が限られ た分子の欠損につながるという知見は大変興味深く、GalNAc 転移酵素遺伝子の欠損と関連した他の疾患の存在も示唆して いる。本研究は特定の GalNAc 転移酵素アイソフォームの変 異に関連したFTCに扔ける高リン血症の分子機構を初めて示 したものである。

\section{References}

1. Kato, K., Jeanneau, C., Tarp, M. A., Benet-Pages, A., Lorenz-Depiereux, B., Bennett, E. P., Mandel, U., Strom, T. M., and Clausen, H. (2006) J. Biol. Chem. 281, 18370-18377

2. Ten Hagen, K.G., Fritz, T. A., and Tabak, L. A. (2003) Glycobiology 13, 1R-16R

3. Hennet, T., Hagen, F. K., Tabak, L. A., and Marth, J. D. (1995) Proc. Natl. Acad. Sci. USA 92, 12070-12074

4. Zhang, Y., Iwasaki, H., Wang, H., Kudo, T., Kalka, T. B., Hennet, T., Kubota, T., Cheng, L., Inaba, N., Gotoh, M., Togayachi, A., Guo, J., Hisatomi, H., Nakajima, K., Nishihara, S., Nakamura, M., Marth, J. D., and Narimatsu, H. (2003) J. Biol. Chem. 278, 573-584

5. Marth, J. D. (1996) Glycobiology 6, 701-705

6. Tenno, M., Ohtsubo, K., Hagen, F. K., Tabak, L. A., and Marth, J. D., (2005) Glycobiology 15, 1238-1239

7. Schwientek, T., Bennett, E. P., Flores, C., Thacker, J., Hollmann, M., Reis, C. A., Behrens, J., Mandel, U., Keck, B., Schafer, M. A., Haselmann, K., Zubarev, R., Roepstorff, P., Burchell, J. M., Taylor-Papadimitriou, J., Hollingsworth, M. A., and Clausen, H. (2002) J. Biol. Chem. 277, 22623-22638

8. Ten Hagen, K. G. and Tran, D. T. (2002) J. Biol. Chem. 277, 22616-22622

9. Topaz, O., Shurman, D. L., Bergman, R., Indelman, M., Ratajczak, P., Mizrachi, M., Khamaysi, Z., Behar, D., Petronius, D., Friedman, V., Zelikovic, I., Raimer, S., Metzker, A., Richard, G., and Sprecher, E. (2004) Nat. Genet. 36, 579-581

10. Ichikawa, S., Lyles, K. W., and Econs, M. J. (2005) J. Clin. Endocrinol. Metab. 90, 2420-2423

11. Specktor, P., Cooper, J. G., Indelman, M., and Sprecher, E. (2006) J. Hum. Genet. 51, 487-490

12. Ichikawa, S., Imel, E. A., Sorenson, A. H., Severe, R., Knudson, P., Harris, G. J., Shaker, J. L., and Econs, M. J. (2006) J. Clin. Endocrinol. Metab. 91, 4472-4475

13. Campagnoli, M. F., Pucci, A., Garelli, E., Carando, A., Defilippi, C., Lala, R., Ingrosso, G., Dianzani, I., Forni, M., and Ramenghi, U. (2006) J. Clin. Pathol. 59, 440-442

14. Garringer, H. J., Fisher, C., Larsson, T. E., Davis, S. I., Koller, D. L., Cullen, M. J., Draman, M. S., Conlon, N., Jain, A., Fedarko, N. S., Dasgupta, B., and White, K. E. (2006) J. Clin. Endocrinol. Metab. 91, 4037-4042

15. Frishberg, Y., Ito, N., Rinat, C., Yamazaki, Y., Feinstein, S., Urakawa, I., Navon-Elkan, P., Becker-Cohen, R., Yamashita, T., Araya, K., Igarashi, T., Fujita, T., and Fukumoto, S. (2007) J. Bone Miner. Res. 22, 235-242

16. Ichikawa, S., Guigonis, V., Imel, E. A., Courouble, M., Heissat, S., Henley, J. D., Sorenson, A. H., Petit, B., Lienhardt, A., and Econs, M. J. (2007) J. Clin. Endocrinol. Metab. 92, 1943-1947

17. Barbieri, A. M., Filopanti, M., Bua, G., and Beck-Peccoz, P. (2007) J. Hum. Genet. 52, 464-468

18. White, K. E., Evans, W. E., O’Riordan, J. L. H., Speer, M. C., Econs, M. J., Lorenz-Depiereux, B., Grabowski, M., Meitinger, T., and Strom, T. M. (2000) Nat. Genet. 26, 345-348

19. Shimada, T., Mizutani, S., Muto, T., Yoneya, T., Hino, R., Takeda, S., Takeuchi, Y., Fujita, T., Fukumoto, S., and Yamashita, T. (2001) Proc. Natl. Acad. Sci. USA 98, 6500-6505

20. Shimada, T., Muto, T., Urakawa, I., Yoneya, T., Yamazaki, Y., Okawa, K., Takeuchi, Y., Fujita, T., Fukumoto, S., and Yamashita, T. (2002) Endocrinology 143, 3179-3182

21. Benet-Pages, A., Lorenz-Depiereux, B., Zischka, H., White, K. E., Econs, M. J., and Strom, T. M. (2004) Bone 35, 455-462

22. White, K. E., Carn, G., Lorenz-Depiereux, B., Benet-Pages, A., Strom, T. M., and Econs, M. J. (2001) Kidney Int. 60, 2079-2086

23. Shimada, T., Kakitani, M., Yamazaki, Y., Hasegawa, H., Takeuchi, Y., Fujita, T., Fukumoto, S., Tomizuka, K., and Yamashita, T. (2004) J. Clin. Invest. 113, 561-568

24. Araya, K., Fukumoto, S., Backenroth, R., Takeuchi, Y., Nakayama, K., Ito, N., Yoshii, N., Yamazaki, Y., Yamashita, T., Silver, J., Igarashi, T., and Fujita, T. (2005) J. Clin. Endocrinol. Metab. 90, 5523-5527

25. Larsson, T., Davis, S. I., Garringer, H. J., Mooney, S. D., Draman, M. S., Cullen, M. J., and White, K. E. (2005) Endocrinology 146, 3883- 
3891

26. Benet-Pages, A., Orlik, P., Strom, T., and Lorenz-Depiereux, B. (2005) Hum. Mol. Genet. 14, 385-390

27. Chefetz, I., Heller, R., Galli-Tsinopoulou, A., Richard, G., Wollnik, B., Indelman, M., Koerber, F., Topaz, O., Bergman, R., Sprecher, E., and Schoenau, E. (2005) Hum. Genet. 118, 261-266

28. Ito, N., Fukumoto, S., Takeuchi, Y., Yasuda, T., Hasegawa, Y., Takemoto, F., Tajima, T., Dobashi, K., Yamazaki, Y., Yamashita, T., and Fujita, T. (2005) J. Bone Miner. Metab. 23, 435-440

29. Sorensen, A. L., Reis, C. A., Tarp, M. A., Mandel, U., Ramachandran, K., Sankaranarayanan, V., Schwientek, T., Graham, R., Taylor-Papadimitriou, J., Hollingsworth, M. A., Burchell, J., and Clausen, H. (2006) Glycobiology 16, 96-107

30. Bennett, E. P., Hassan, H., Mandel, U., Mirgorodskaya, E., Roepstorff, P., Burchell, J., Taylor-Papadimitriou, J., Hollingsworth, M. A., Merkx, G., van Kessel, A. G., Eiberg, H., Steffensen, R., and Clausen, H. (1998) J. Biol. Chem. 273, 30472-30481

31. Wandall, H. H., Hassan, H., Mirgorodskaya, E., Kristensen, A. K., Roepstorff, P., Bennett, E. P., Nielsen, P. A., Hollingsworth, M. A., Burchell, J., Taylor-Papadimitriou, J., and Clausen, H. (1997) J. Biol. Chem. 272, 23503-23514

32. Bennett, E. P., Hassan, H., Mandel, U., Hollingsworth, M. A., Akisawa, N., Ikematsu, Y., Merkx, G., van Kessel, A. G., Olofsson, S., and Clausen, H. (1999) J. Biol. Chem. 274, 25362-25370

Received on October 24, 2007, accepted on November 12, 2007

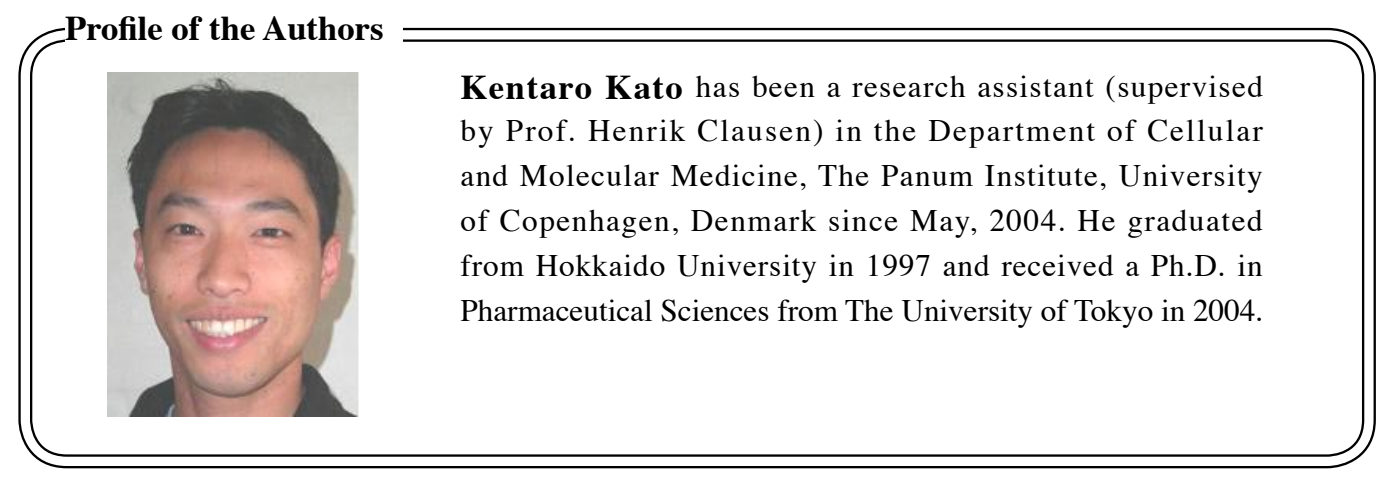

